\title{
A critical look at the terms feminism, Feminism, and womanism and the applicability, or not, of each in conversation with Toni Morrison's First and Last Novels The Bluest Eye and Home
}

\author{
Lauren Malotra-Gaudet ${ }^{\mathrm{a}}$
}

\section{Introduction}

For the purpose of this paper lower-case-f feminism is used as the umbrella term for the organized activity in support of women's rights and interests founded in the belief that men and women should have equal rights and opportunities. Hegemonic Feminism, aka Radical Feminism, has historically left out women who face issues alongside oppression based on gender, namely women of colour. Capital-F Feminism represents this hegemonic Feminism. Alice Walker's womanism creates a type of feminism specifically for black women and women of colour. In this paper I explore and contrast three different types of feminism, hegemonic "Feminism" and "womanism", to show how Toni Morrison's first and last novels The Bluest Eye and Home are definitely womanist texts but are not necessarily considered feminist under the constraints of hegemonic Feminism. I look at the differences between the three terms to show how these novels can and do slip through the cracks and are not labeled as "feminist" texts because they do not comply with "Feminism." Through plot and character examples I show how these novels are womanist, and because of that they are not able to be considered examples of Feminist texts and are therefore not regarded as canonical Feminist literature, though they do exemplify feminist principles, themes and ideals.

\section{Feminism and its Exclusive Foundation:}

The first branch of "feminism" that I will explore is "Feminism." Seemingly harmless, and seemingly no different, when used as an arm of "feminism," Feminism and Feminist ideals can be detrimental to "feminism" as it is easy to conflate the two (because, after all, they sound the same and technically are the same word--which makes it easier for people to believe that the written "Feminism" is the true form of feminism). Hegemonic Feminism, often called "Radical Feminism" but sometimes just called "Feminism" is the most "extreme" form of feminism. Feminism take feminism's definition of "the belief that men and women should have equal rights and opportunities" and "organized activity in support of women's rights and interests" to the most extreme and literal sense. American Feminism has its roots in the Women's Rights Movement. Any student of Advanced Placement United States History remembers well memorizing the first US Women's Rights convention at Seneca Falls in 1848. However, it is arguable how many people remember how many black people were at the convention (one, Frederick Douglass) and how many black women were at the convention (none). We look to this convention as the foundation of the women's rights movement, later to be called the Feminist movement, but from the very beginning at Seneca Falls black women and black women's voices were left out. Since the Declaration of Sentiments of the Seneca Falls Convention black women were not included or thought of; which translates to modern day black women's exclusion in Feminism and Feminist movements.

"Radical Feminism, the most extreme version of all feminisms, is mainly composed of white women who are looking for their rights in a patriarchal society that denies their freedom. Its main concern is with patriarchy in forms of male control, dominance, and preference throughout all institutions of society as the center of gender oppression" (Deyab, 10). Feminism's foundation and continued emphasis on fighting the patriarchy and women's oppression inherently leaves out other women who face issues alongside oppression based on gender. In her book Feminism, Jane Freedman attempts to find commonality between all strains of feminism and defines feminism (the overarching term) as:

Any attempt to provide a baseline definition of a common basis of all feminisms may start with the assertion that feminisms concern themselves with women's inferior position in society and with discrimination encountered by women because of their sex. Furthermore, one could argue that all feminists call for changes in the social, economic, political or cultural order, to reduce and eventually overcome this discrimination against women. (Freedman, 1)

Freedman does a good job trying to define what feminism is, with regards to herself and her interests, and does, in fact, define Feminism. Freedman defines Feminism, and not feminism, here because she asserts that "feminisms concern themselves with women's inferior position in society and with discrimination encountered by women because of their sex." This assertion claims that the issue faced by women, across all other social identities, is their womanhood and discrimination solely on this front. We can see that this argument is a purely Feminist argument, because Freedman asserts that is only and especially women's womanhood that is the platform they are discriminated against the most on. Her assertion shows that she believes that women are only placed in an "inferior position in society" because of "their sex."

Freedman is reflecting the position of the Seneca Falls Convention into the 2000s; returning to the Seneca Falls Declaration of Sentiments "The history of mankind is a history of repeated injuries and usurpations on the part of man 
toward woman, having in direct object the establishment of an absolute tyranny over her." Both the women that attended the Seneca Falls Convention and Freedman can find comfort in this idea that the history of mankind exists the way is does because of a series of injuries and injustices that were inflicted on history's female counterparts. Freedman attempts to argue that feminism is comprised of only three branches, liberal feminism, Marxist feminism, and radical feminism (Freedman, 5). Freedman only mentions identity-inclusive feminisms in passing, as an "added on" category of feminism and not a major/important movement (Freedman, 5) and continues to reiterate that "The liberation of women this depends on freeing women from this social construction of the 'eternal feminine', which has rescued them to a position of social and economic inferiority" (Freedman, 14). This belief that gender is the sole identity marker for inequality or difference to be tackled is the most common misconception and principal that is associated with Feminism, Feminists, and Feminist critiques. Feminism remains to be centered on gender inequity, and Radical Feminism the most so. "Feminism, especially the Radical part of it, has identified 'men as the agents of oppression,' and argue that 'all other forms of exploitation and oppression (racism, capitalism, imperialism, etc.) are all extensions of male supremacy' (Joseph and Lewis, 55)" (Deyab, 12). Fundamentally Feminists argue that "all men are the enemies of all woman and proposed solutions to this problem a utopian woman nation, separatist communities, and even the subjugation or extermination of all men" (hooks Feminist Theory, 34). While I won't go so far as to say that all Feminists believe in such extreme principals as male extermination, the recentering of all women's struggle on men/complete blame of men and the patriarchal system is At its core, Feminism believe that men are the enemy and male domination/female subordination (in the male-female power dichotomy) must be challenged.

\section{Feminism versus feminism:}

For the purpose of this paper lower-case-f feminism is used as the Oxford English Dictionary and Merriam-Webster dictionaries define it: "the belief that men and women should have equal rights and opportunities," and "the advocacy of women's rights on the grounds of political, social, and economic equality to men." Lower-case-f feminism is the umbrella term that encompases the other three terms that I will be using in this paper, along with others, other movements, and related topics and movements. feminism is a collection of movements and ideologies. While Feminism focuses on oppression based on gender (specifically biologically female assigned at birth and female identified people's oppression) as the sole/most important form of oppression, and all other oppressions second, or in some cases not relevant to "the Feminist fight/movement," the umbrella term feminism allows other feminist movements to still be counted at the same level as others.

Feminism has been taken to mean feminism, and it is this misconception (and the aggressive creation of Feminism) that has lead to the need for others to branch off entirely from feminism to create other terms and other identities that are not readily associated with Feminism (and, because they are the same word, feminism). "Feminism has even been attacked by the feminists themselves who see the Feminist movement as anti-male, anti-child, anti-family, anti-feminine. And therefore it has nothing to do with us" (Quinn, 143). Womanism, as we will see, is under the umbrella of feminism and has the ability to be included under that term; but it do not have the ability to be included as a subgroup of Feminism, because Feminism is inherently more radicalized to be just focused on the oppression of women based on their gender (woman) identity by men. Feminism is exclusive, feminism is inclusive.

\section{Womanism:}

At the beginning of Alice Walker's In Search of Our Mother's Gardens: Womanist Prose she defines womanism as:

Womanist 1. From womanish (Opp. of "girlish," i.e., frivolous, irresponsible, not

serious.) A black feminist or feminist of colour. From the black folk expression of mothers to female children, "You acting womanish," i.e., like a woman. Usually referring to outrageous, audacious, courageous or willful behavior. Wanting to know more and in greater depth than is considered "good" for one. Interested in grownup doings. Acting grown up. Being grown up. Interchangeable with another black folk expression: "You trying to be grown." Responsible. In charge. Serious.

2. Also: ... Committed to survival and wholeness of entire people, male and female.

3. ... Loves the Folk. Loves herself. Regardless.

4. Womanist is to feminist as purple to lavender. (Walker, xi-xii)

In these definitions there are many key elements that we need to tease out to later apply to Morrison's novels and to the comparison between womanism and Feminism. First and foremost is the emphasis on the "folk" aspects of the definition. Womanism/womanist is an identity that is inclusive of black men because womanism is focused on the "survival and wholeness of entire people" specifically a wholeness/reunification of the black identity which must be inclusive of black men. Womanism also takes into account that black men are subjected to racism as are black women, and should not be left out of an equality/equalizing identity and movement. "They have not taken a stand against their fellow men just because they are men. Rather, they believe that any healing process for African-American women should include African-American men as well... [because] they believe that their men are also oppressed by white supremacy, and that the problems of African-American women and men are much the same, and as such requires common ground and understanding to fight the oppressions they are facing" (Deyab, 12).

Hooks in her book, Ain't I A Woman, asserts that "as far back as slavery, white people established a social hierarchy based on race and sex, that ranked white men first, white women second, though sometimes equal to black men who ranked third, and black women last" (53). Womanism is the response to these systems, placing racism and sexism in conversation with each other, not segregated to different places under the "feminist" umbrella. Womanism is a response to this hierarchal system, a rejection of the classifications of white people and a creation of a system for gender equity all its own. In an interview with Anne Koenen, 
Morrison said: "It seems to me historically true that Black women have a special place in this culture, which is not always perceived an enviable one. One of the characteristics of Black women's experience was that they did not have to choose between a career and a home. They did both" (Morrison, "Conversations with Toni Morrison" 72).

\section{Womanism versus Feminism:}

It may be clear already through the previous sections, but there are drastic differences between womanism and Feminism that make it impossible for some of Toni Morrison's novels to be read as Feminist but quite simple for them to be read as womanist. Before even getting to Morrison though, I would first like to point out the extreme differences in the origins of the two words, womanism coming from "folk" origins, Feminism finding its derivative from French, originated in the 19th century. This already apparent class difference aside, there are the more subtle/less visible to those involved differences between Feminism and womanism. Feminism and womanism also differ on their reception of men and male support in their movements and actions. "Unlike Radical Feminists, African-American women have not disassociated themselves from the men of their community" (Deyab, 12). The origin of each word and their inclusion of men seem like minor differences, so I will now explain a few more major areas of deviation between womanism and Feminism.

For example, there is again the major issue of black women not being included in the Feminist movement. "Some African-American women believe that they are manipulated by white Radical Feminists and even are dehumanized by them, and that white women are using African-American women to gain 'a female victory in the white sexual, political game' (Ogunyemi, "Womanism" 236)" (Deyab, 1). hooks articulates very clearly this sense of being left out of the Feminist movement in Feminist Theory:

When I participated in feminist groups, I found white women adopted a condescending attitude towards me and other non-white participants.. .they did not see us as equals. They did not treat us as equals.... If we dared to criticize the movement or to assume responsibility for reshaping feminist ideas and introducing new ideas, our voices were turned out, dismissed, silenced. We could be heard only if our statements echoed the sentiments of the dominant discourse. (hooks, 12-13)

When thinking of why black women are not considered an obvious part of the Feminist movement, it is clear they they just do not fit into the definition of "Feminism." Part of Morrison's problem with the Feminist movement is that it has been controlled by the ideologies of upper-middle-class white women. As she puts it:

The early image of women's lib was of an elitist organization made up of upper- middle-class women with the concerns of that class (the percentage of women in professional fields, etc.) and not paying much attention to the problems of most

black women, which are not in getting into the labor force but in being upgraded in it, not in getting into medical school but in getting adult education, not in how to exercise freedom from ' the head of the house' but in how to be head of the household. (Morrison, "What the Black Women Thinks about Women's Lib" 16)

Morrison's critique is not an uncommon one. Black women have criticized the Feminist movement as inadequately confronting the issues facing them and have accused it of concentrating only on the perspectives and concerns of white, middle-class women. hooks put it plainly when she wrote that"bourgeois white women had defined feminism in such way as to make it appear that it had no real significance for black women" ( Feminist Theory, hooks, 33).

Additionally, one of the strongest critiques of the Feminist movement is its necessitation for participants in it to choose amongst their important identities to put gender first (and oftentimes to only see gender as a problem). Feminism as a concept is not intersectional, it is exclusively focused on gender-based subjugation and that alone. For women that face other problems, have other identities that continue to be subjugated, and are discriminated against for other things than just their gender, Feminism does not make sense. We return again to hooks' experience to comment on this issue:

As a black woman interested in the Feminist movement, I am often asked whether being black is more important than being a woman; whether feminist struggle to end sexist oppression is more important than the struggle to end racism or vice versa. (Feminist Theory, hooks 31)

In other words, for African-American women, there are larger problems than sex and gender, such as race, class, and poverty that women all over the world are struggling with. Because of these problems, many African-American women and women of color consider the Feminist movement as "completely irrelevant to black women in particular or the black struggle in general' (Beal 12)" (Deyab, 13).

\section{The Bluest Eye:}

"In her novel The Bluest Eye (1981), Toni Morrison graphically depicts the effects of the legacy of nineteenth-century classical racism for poor black people in the United States. The novel tells of how the daughter of a poor black family, Pecola Breedlove, internalizes white standards of beauty to the point where she goes mad. Her fervent wish for blue eyes comes to stand for her wish to escape the poor, unloving, racist environment in which she lives" (Weedon).

The Bluest Eye focuses on Pecola and her obsession with whiteness and white culture, as seen through Claudia's eyes. Claudia and Pecola make an interesting point of comparison regarding womanism and Feminism, as it seems that Claudia is the voice of womanism, and more of the voice of Morrison, and Pecola is the voice of a black girl trying to fit into Feminism. Pecola is a prime person to use as a comment on black women's exclusion from Feminism because, as an impressionable child, she is the mark of innocence; black innocence, shaped in the harassing environment that is white America. "Morrison's choice of a child, the most vulnerable to the impact of these stereotypes [white standards of beauty], as a protagonist in The Bluest Eye indicates her womanist desire to show the effect of submitting to the society's standards of beauty on the soul of a would-be AfricanAmerican woman" (Deyab, 45). Morrison commented on this herself in an interview: "In The Bluest Eye, I try to show a little girl as a total and complete victim of whatever around her" (Stepto, 17). She isn't just writing about the desire to be 
"beautiful" (in this case, white, as Pecola conflates beauty with whiteness in her desire to have blue eyes, a more sloped nose is not enough for her), but Morrison is writing on the desperation to be recognized as beautiful, to be seen in the foreground and not the background:

"I began to write about a girl who wanted blue eyes and the horror of having that wish fulfilled; and also about the whole business of what is physical beauty and the pain of that yearning and wanting to be somebody else, and how devastating that was and yet part of all females who were peripheral in other people's lives. (Ruas 9596)" (Deyab, 45-6)

Now that we see some of what Morrison's intentions were for the novel, we can look more into how and why it is an acutely womanist text. Morrison heavily focuses on the issue of race and being raised not white in a white preferencing society. This narrative is exclusively not Feminist because intermixed in it (and playing a major role) is the impact that being not white has on the body and the individual's perception of themself and their existence. Morrison puts Claudia and Pecola's relationships outlooks on Feminism and Feminist standards of beauty/inclusion in contrast with one another to show more clearly the need for womanism and an inclusive, non white-focused, means of looking at the world and the self.

We see most clearly Claudia's womanist perspectives in the scenes leading up to and after her receiving the baby doll for Christmas. Before we even know she gets a blue-eyed baby doll, we know that she hates Shirley Temple because she danced with Bojangles, and Bojangles should be Claudia's:

I hated Shirley. Not because she was cute, but because she danced with Bojangles, who was my friend, my uncle, my daddy, and who ought to have been softshowing it and chuckling with me. Instead, he was enjoying, sharing, giving a lovely dance thing with one of those little white girls whose socks never slid down under their heels (Morrison The Bluest Eye, 19)

Remembering back to the definition of womanism, key to it (and its deviance from Feminism) is its inclusion of (black) men. Claudia sees more relation to Bojangles than she does Shirley, even though they are both girls of around the same age, and thinks that Bojangles should be with her. Claudia sees Bojangles, and not Shirley, as a member of her community; this is a uniquely womanist view.

Claudia also could not understand why the white baby doll was supposed to be an amazing gift. She could not understand perspectives like that of Pecola, who idolized the thing. She was in charge and serious in her investigation of the idealized whiteness of the doll, to no avail:

But before that I had felt a strange, more frightening thing than hatred for all the Shirley Temples of the world.

It had begun with Christmas and the gift of dolls. The big, the special, the loving gift was always a big, blueeyed Baby Doll. From the clucking sounds of adults I knew that the doll represented what they thought was my fondest wish... I had only one desire: to dismember it. To see of what it was made, to discover the dearness, to find the beauty, the desirability that had escaped me, but apparently only me. Adults, older girls, shops, magazines, newspapers, window signs--all the world had agreed that a blue-eyed, yellow-haired, pink-skinned doll was what every girl child treasured... I could not love it. But I could examine it to see what it was that all the world said was lovable (Morrison The Bluest Eye, 19-21) Claudia could not understand why there was a preference to white baby dolls over love and inclusion in her own community. When thinking to herself of what she really wanted for christmas, rather than being thrust into white America's beauty standards, Claudia just wanted to experience her family and her elders. She wanted to know that she was loved and safe in the company of her grandparents, and to know that there was the security of her community to return to:

Had any adult with the power to fulfil my desires taken me seriously and asked me what I wanted, they would have known that I did not want to have anything to own or to possess any object. I wanted rather to feel something on Christmas Day... "I want to sit on the low stool in Big Mama's kitchen with my lap full of lilacs and listen to Big Papa play his violin for me alone" (Morrison The Bluest Eye, 21-2)

Instead, her family gives her a white baby doll, their perception of the "most beautiful" gift a child could receive.

Claudia's prioritization of her family, elders, confusion with white America's beauty standards, and desire to be connected to black men over white girls contrasts greatly with the experiences and thoughts of Pecola. Pecola is taken in by Claudia's mother, a woman of the neighborhood doing her communal duty to help a family in need. But when Pecola is first introduced to the Shirley Temple cup and Shirley's perfect whiteness, all semblances of manners and womanist solidarity go out the window. When Pecola drinks three quarts of milk just so she can spend more time with the Shirley Temple cup looking into her beauty she has no regard for Mrs. MacTeer and the love and help she has shown her and community bonds through taking in Pecola; Pecola only cares about Shirley's beauty. Pecola is again shown idealizing and ingesting whiteness when she turns to the Mary Janes candies to soothe her pain:

Each pale yellow wrapper has a picture on it. A picture of little Mary Jane, for whom the candy is named. Smiling white face. Blonde hair in gentle disarray, blue eyes looking at her out of a world of clean comfort. The eyes are petulant, mischievous. To Pecola they are simply pretty. She eats the candy, and its sweetness is good. To eat the candy is somehow to eat the eyes, eat Mary Jane. Love Mary Jane. Be Mary Jane.

Three pennies had brought her nine lovely orgasms with Mary Jane. Lovely Mary Jane, for whom a candy is named (Morrison The Bluest Eye, 50)

Pecola is only content when she was literally consuming whiteness. Either from the Shirley Temple cup or the Mary Janes, Pecola's only joy in the entire novel is when she is consuming or thinks she has become whiteness. She is completely taken over by white culture and her need to be loved--love that is only possible for white girls to receive. Pecola is not only a sad case because of her internalized ideal of whiteness, but also because she has completely rejected any and all womanist sentiments. She is immature, irrational, self seeking, and does not love the folk or herself. Not only is it her unfortunate idealization of whiteness that leads to her downfall, but it is also the rejection of womanism. 
Female characters aside, The Bluest Eye is a womanist text not only because of its focus on the centrality of black girl's focus on whiteness and hegemonic whiteness translating into beauty standards across race. The Bluest Eye is womanist also because of Morrison's inclusion of black men and black boy's experiences socialized into white America. When the group of boys harassed Pecola to taunt her:

That they themselves were black, or that their own father had similarly relaxed habits was irrelevant. It was their contempt for their own blackness that gave the first insult its teeth. They seemed to have taken all of their smoothly cultivated ignorance, their exquisitely learned self-hatred, their elaborately designed hopelessness and sucked it all up into a fiery cone of scorn that had burned for ages in the hollows of their minds--cooled--and spilled over lips of outrage, consuming whatever was in its path. They danced a macabre ballet around the victim, whom, for their own sake, they were prepared to sacrifice to the flaming pit. (Morrison The Bluest Eye, 65)

There is no way a scene like this could be read as Feminist. However, we can see parallels in the boy's anguish and selfhatred, instilled by white America, to that of Pecola. They do not care anymore about any race-based connections they may have to Pecola, their teasing is simply a matter of projecting their own self hatred. This connection in the struggle against white American socialization unifies the strifes of Pecola and her tormentors in a uniquely womanist way.

\section{Home:}

In Home, the key reflection of Morrison's womanist writing is in her focus on the community of women and their impact of various female characters throughout the story. While they are not a major part of the novel, especially because their importance is mentioned in the final quarter of the novel, their impact can easily be looked past. From a Feminist standpoint this novel doesn't even have any major female characters with roles. We don't know the back stories of most of the women, they barely even come into the story until the end (other than through Frank's memories), and Cee is just a transitory character who Frank needs to save, so you can argue that they are only relevant in their positionality to Frank, the presumed "main character" of the novel. This wrong interpretation of Morrison's writing is just why a Feminist lens cannot be applied to the story. Home is the story of Cee and her need for the love and community of black women of Lotus, Georgia. The community of women as a unit is the main character of the unwritten story (the back story, what is going on in between Morrison's writing), arguably the most important part of the story because that is when Cee is healed and changed. The women are impactful on those members of the community that actively embrace them and that do not--this inclusion is a very important component of womanism, a component that we also saw in The Bluest Eye.

From the unnatural relationship of Lenore and Lenore, we are expected to believe that her selfishness caused her stroke. Morrison uses Lenore to teach a life lesson on the greater importance of the black women's community: that black women need community and communal love/care in order to thrive: "Now she had to be content with the company of the person she prized most of all--herself. Perhaps it was the partnership between Lenore and Lenore that caused the minor stroke" (Morrison Home, 92). Still, she is taken care of by the community of women, Morrison's comment on the value of womanism's communal nature over the force of Feminism's solitary discourse of individual-woman's successes:

It was a testimony to the goodwill of churchgoing and God-fearing neighborhood women that they brought her plates of food, swept the floors, washed her linen, and would have bathed her too, except her pride and their sensitivity forbade it. They knew that the woman they were helping despised them all, so they didn't even have to say out loud what they understood to be true: that the Lord works in Mysterious Ways His Wonders to Perform (Morrison Home, 92)

Lenore ignored the women, but still it was the community women that end up helping her. The lord works in mysterious ways, giving Lenore and her safekeeping to the people she despised, because in the end they are all that she had. Her refusal to befriend or become a part of the community of women left her on the outside, alone to her greed. From a traditionally Feminist standpoint, there is no issue with Lenore's self seeking nature. A Feminist analysis could go so far as to say that she took her life into her own hands, wrote her own story, chose her partners, and maintained her wealth in ways that could parallel male counterparts. What's important is Lenore's capitalistic success, from a Feminist standpoint, but from a womanist lens we are learning a lesson from Lenore's story.

As soon as Frank brings Cee to the women, he is shooed away and the focus is on Cee, her recovery, and the women's role in that recovery. "He was blocked by visiting the sick room by every woman in the neighborhood... they believed that his maleness would worsen her condition" (Morrison Home, 119). With regards to Cee's recovery, it was the "demanding love of Ethel Fordham which soothed and strengthened her the most" (Morrison Home, 125). While Frank was integral in helping to save Cee and bring her home, all he was was the messenger to the story. Home is about Cee's return to Lotus, Georgia. We can look upon Home not as the story of "Frank [the] modern Odysseus returning to a 1950s America mined with lethal pitfalls for an unwary black man," but rather a coming of age story for Cee (Morrison Home, back cover). Frank's job is to bring Cee to the women so that she can grow and change from "the girl who trembled at the slightest touch of the real and vicious world" (Morrison Home, 127). He experiences growth too, because of Cee. If it were not for Cee's danger, Frank could have ended up in the gutter somewhere never to be heard from again, but because he received a letter (from a woman in the black community) calling for him to save his sister, he comes to her rescue: rescue in the form of the community of black women in Lotus.

\section{Conclusion:}

One of the primary goals of womanism is to record African-American women's experience by making their voices heard, through expanding their studies beyond issues important to privileged white women. Unlike the struggle of their white counterparts, womanists' main struggle is against racism and sexism that encourage many of the stereotypes that are closely associated with African-American women. In 
their writings, womanists present growing up AfricanAmerican female in America as a painful experience in "a white-supremacist society; a society that is everywhere everyday of our lives urging us to hate Blackness and ourselves" (hooks, Sisters 80). Through looking more closely at the definitions of Feminism and womanism, and their similarities and departures from that of feminism, we have been offered a more clear lens through which to view certain instances from The Bluest Eye and Home. We can see that these texts cannot easily fall under the Radical Feminist definition, and therefore can be easily shrugged off as not being feminist as well. However, by looking at the ways in which each embody the definition of womanism, we can see that they do count as novels that can fall under the feminist umbrella, on the side of womanism. "Morrison's interest in depicting the daily struggle of African-American women makes her a womanist writer" (Deyab, 36).

\section{Bibliography:}

Deyab, M. (2004). Toni Morrison's womanist discourse in The Bluest Eye (1970), Sula (1974), and Beloved (1987): Analytical and computational study. Carbondale, Illinois: Southern Illinois University Carbondale.

Collins, P. (2001). WHAT'S IN A NAME? Womanism, Black Feminism, and Beyond. The Black Scholar, 26(1), 9-17.

"Feminism." Def. 1. Merriam-Webster Online. MerriamWebster, n.d. Web. 5 May. 2014.

"Feminism."" Def. 2. Oxford Dictionaries Online. Oxford Dictionaries, n.d. Web. 5 May. 2014.

Freedman, J. (2001). Feminism. Buckingham Pa.: Open University Press.

Hooks, B. (1984). Feminist theory from margin to center. Boston, MA: South End Press.

-. (1992). Ain't I A Woman: Black Women and Feminism. Boston, MA: South End Press.
- (1993) Sisters of The Yam: Black Women And SelfRecovery. Boston, MA: South End Press.

Halsall, P. (1998, August). Modern History Sourcebook: The Declaration of Sentiments, Seneca Falls Conference, 1848. Retrieved May 8, 2014, from http://www.fordham.edu/halsall/mod/senecafalls.asp

Morrison, T., \& Guthrie, D. (1994). Conversations with Toni Morrison. Jackson: University Press of Mississippi.

— . (2012) Home. New York: Alfred A. Knopf.

- (1994). The Bluest Eye. New York: Plume Book.

- . (1971, August 22). What the Black Women Thinks about Women's Lib. New York Times Magazine.

Ogunyemi, C. (1993). Womanism: The Dynamics of the Contemporary Black Female Novel in English (V. Clarke, R. Joeres, \& M. Sprengnether, Eds.) Revising the Word and the World: Essays in Feminist Literary Criticism, 231-248.

Quinn, Sally. (1995) "Feminism is Obsolete." (Ed. Carol Wekesser.) Feminism: Opposing Viewpoints. San Diego, CA: Greenhaven Press, Inc. 139-144.

Silvera, Makeda. (1992) "Man Royals and Sodomites: Some Thoughts on the Invisibility of Afro-Caribbean Lesbians." Feminist Studies 18.3, The Lesbian Issue, 521-32.

Stepto, R. (1994). Intimate Things in Place: A Conversation with Toni Morrison. Jackson: University Press of Mississippi. 10-29.

Walker, A. (1983). In search of our mothers' gardens: Womanist prose. San Diego: Harcourt Brace Jovanovich. Weedon, C. (2002). Key Issues in Postcolonial Feminism: A Western Perspective. Gender Forum: An Internet Journal for Gender Studies, 1, 1-5. 